Olena DIAHYLEVA,

orcid.org/0000-0003-3741-4066

Doctor of Philosophy,

Vice Rector on Academic Work

Kherson State Maritime Academy

(Kherson, Ukraine) elena.dyagileva80@gmail.com

Olha TOKARIEVA,

orcid.org/0000-0001-9566-0017

Candidate of Pedagogical Sciences,

English teacher

Maritime Applied College of Kherson State Maritime Academy

(Kherson, Ukraine) otokareva261276@gmail.com

Iryna DENYCHENKO,

orcid.org/0000-0001-7065-9634

English Teacher at the Ship Engineering Department

Maritime Applied College of Kherson State Maritime Academy

(Kherson, Ukraine) denychenko21@gmail.com

Natalya YARESKO,

orcid.org/0000-0001-9731-6359

English Teacher at the Ship Engineering Department

Maritime Applied College of Kherson State Maritime Academy

(Kherson,Ukraine) natayaresko1@gmail.com

\title{
ROLE OF DISTANCE LEARNING IN SPEECH CULTURE FORMATION OF FUTURE MARITIME SPECIALISTS DURING ACADEMIC AND PRACTICAL TRAINING
}

The article outlines a number of factors that have a direct impact on the requirements for practical training of marine professionals in terms of continuous improvement of both technical and technological level of equipment on modern vessels and various requirements of international standards in the field of shipping. The aim is to theoretically justify, develop and experimentally test the results of students 'professional training, namely the competent specialist in demand in the labor market, who has the most effective algorithms for action in normal and emergency situations on board a ship. Results. The main stages of practical training in the Maritime Vocational College of the Kherson State Maritime Academy are analyzed, the continuity of stages is proved, which aims to form and comprehensively develop the knowledge, skills and abilities necessary for a competent and competitive maritime specialist. The role of fluency in English as a working language of the multilingual team and a key condition for the safe operation of a vessel is determined. The article outlines the basic and most commonly used methods and tools applied in the course "English for Professional Purposes" to develop students' skills of communication within the speech culture as an important part of professional competence. The challenges of organizing an effective learning process in the context of distance learning are analyzed and as a result of generalizing the experience of teachers of the subject commission of English the most effective types of tasks that keep training of students to practice at a high level in all courses are defined. Special attention has been given in particular to the tasks that develop listening comprehension of speech as one of the key skills in working communication. There is a wide range of opportunities to accurately assess the level of competence of students with the help of tests, as the teacher can develop tasks independently according to the level of the group, the characteristics of the topic being studied, and a number of other factors. The use of testing as a routine form of training and control allows students to develop skills in passing tests in crewing companies, which is a share of the selection process under the cadet program among market leaders. Conclusion. The article reveals the educational sailing and industrial sailing practice as one of the factors of formation of speech culture in the conditions of distance learning in the process of professional training of future specialists in the maritime industry. It is established that sailing practices provides consolidation of theoretical knowledge gained by cadets in the study of special disciplines, the formation of professional skills in accordance with the qualifications and acquired occupations, practical development of modern equipment and gain the necessary experience in using a foreign language.

Key words: practical training, working communication, speech culture, foreign language. 
Олена ДЯГИЛЕВА,

orcid.org/0000-0003-3741-4066

кандидат педагогічних наук,

проректор з навчально-методичної роботи

Херсонської державної морської академії (Херсон, Україна) elena.dyagileva80@gmail.com

Ольга ТОКАРЕВА, orcid.org/0000-0001-9566-0017 кандидат педагогічних наук, викладач англійської мови Морського фахового коледжу Херсонської державної морської академії (Херсон, Україна) otokareva261276@gmail.com

Ірина ДЕНИЧЕНКО, orcid.org/0000-0001-7065-9634 викладач англійської мови судномеханічного відділення Морського фахового коледжу Херсонської державної морської академї (Херсон, Україна) denychenko21@gmail.com

Наталя ЯРЕСЬКО, orcid.org/0000-0001-9731-6359 викладач англійської мови судномеханічного відділення Морського фахового коледжу Херсонської державної морської академії (Херсон, Україна) natayaresko1@gmail.com

\title{
РОЛЬ ДИСТАНЦЙНОГО НАВЧАННЯ У ФОРМУВАННІ МОВЛЕННСВОЇ КУЛЬТУРИ МАЙБУТНІХ СПЕЦААЛСТІВ МОРСЬКОЇ ГАЛУЗІ ПІД ЧАС АКАДЕМІЧНОЇ ТА ПРАКТИЧНОЇ ПІДГОТОВКИ
}

\begin{abstract}
У статті окреслено коло факторів, щуо мають безпосередній вплив на вимоги до практичної підготовки здобувачів морської фахової освіти в умовах постійного вдосконалення як техніко-технологічного рівня оснащення сучасних суден, так і різнопланових вимог міжнародних стандартів у иарині судноплавства. Мета полягає у визначенні, розвитку та експериментальній перевіриі результату професійної підготовки здобувачів освіти, такого як компетентний, затребуваний на ринку праці фахівецьь, щзо володіє максимально ефективними алгоритмами дій в умовах штатних та надзвичайних ситуацій на борту судна. Результати. Проаналізовано основні етапи практичного навчання в Морському фаховому коледжі Херсонської державної морської академії, доведено спадкоємність етапів, щзо має на меті формування $і$ всебічний розвиток знань, умінь та навичок, необхідних для компетентного і конкурентоспроможного фахівия морської галузі. Визначено роль вільного володіння англійською мовою як робочою мовою полімовної команди як ключової умови безпечного функиіонування судна. У статті окреслено базові і найбільш вживані методи та засоби, які використовуються в межах курсу "Англійська мова за професійним спрямуванням» для формування у здобувачів освіти навичок спілкування у рамках мовленнєвої культури як важливої частини професійної компетентності. Проаналізовано виклики щзодо організації ефективного навчального процесу в умовах дистанційного навчання та в результаті узагальнення досвіду викладачів предметної комісії англійської мови визначено найбільш ефективні види завдань, щчо дали змогу втримати підготовку здобувачів освіти до проходження практики на високому рівні на всіх курсах. Особливу увагу приділено зокрема завданням, щзо дають змогу розвинути розуміння мови на слух як одне з ключових умінь в робочій комунікації. Розкрито широкий спектр можливостей точно оцінити рівень компетентності здобувачів освіти за допомогою тестів, оскільки викладач може розробляти завдання самостійно відповідно до рівня групи, особливостей теми, щзо вивчається, та низки інших факторів. Використання тестування як рутинної форми навчання та контролю уможливлює формування у здобувачів освіти навичок проходження тестів у крюїнгових компаніях, щзо становить питому частку проиесу відбору в межах кадетської програми серед лідерів ринку. Висновок. У статті розкрито навчальну плавальну та виробничу плавальну практики як один із чинників формування мовленнєвої культури за умов дистанційного навчання у процесі професійної підготовки майбутніх фахівців морської галузі. Встановлено, ще плавальні практики забезпечують закріплення теоретичних знань, одержаних курсантами під час вивчення спеціальних дисциплін, формування професійних вмінь і навичок у відповідності з кваліфікаційними характеристиками $і$ здобутими робочими професіями, практичного освоєння сучасного обладнання і одержання необхідного досвіду з використання іноземної мови за фахом.
\end{abstract}

Ключові слова: практична підготовка, робоча комунікація, мовленнєва культура, іноземна мова. 
Problem statement. Requirements of modern times in our society as well as all over the world challenge specialists of multiple disciplines to respond wide range of issues which cover all spheres of our life. Education is the source which provides opportunities of growth and improvement, professional progress and application of own abilities.

Dynamics of scientific and technological progress, socio-economic transformations, increasing competition in the labor market, European integration processes in science and education determine modern societal requirements for the training of competent professionals, including the maritime industry with a high level of technical and technological training and culture (speech culture). At the same time, this requirement is determined by international and national standards for the level of training of marine professionals, which ensures their integration in the global professional community. The specified goals form simultaneously the idea about a final result of an activity and professional intent of qualified specialists and are the reference point for essential competencies formation (STCW, 1995). Progressive educators and shipping companies emphasize the urgency of this problem. Given the above, it is advisable to rethink the content and objectives of efficient training of future professionals in the maritime industry in the context of the speech culture formation, as one of the conditions for safe navigation in international crews.

Resent research and publication. Modern scientific intelligence is aimed at multidirectional study of professional training for future specialists in maritime industry in particular. Problems of theoretical, methodological, methodological principles of professional training of future specialists of sea and river transport are covered in the works of M. Bulatov, S. Voloshinov, M. Miyusov, I. Sokol, V. Chernyavsky, etc. The issues of professional training in the psychological aspect are studied by A. Danilenko, V. Dmitriev, T. Zaitseva, O. Istomina, G. Kryvorotko, M. Orlova, M. Yanchuk and others. In the scope of future fleet specialists professional training the formation of communicative multicultural competency and certain aspects of foreign language component are clued by researchers N. Bobrysheva, S. Kozak, O. Myronenko, O. Solovyova, M. Soter, L. Stupina, O. Tyron, O. Frolova etc. The status of the problem of maritime English formation and functioning is summarized in the works of N. Berg, K. Cole, R. Prasad, P. Trenker, J. Hork, etc. However, the research results on terms of peculiarities of fleet specialists professional training provide insufficient fragmentary coverage of speech culture formation of cadets in maritime higher educational institutions. Therefore, the solution of this issue, namely the identification of ways to form the speech culture of future professionals in terms of integrating technical and language education in the training process, is relevant. Practical training is one of such ways.

The purpose of the article: to show practical training on river and sea fleet vessels as an essential factor in speech culture formation of future specialists of maritime industry in the process of professional training in a modern higher educational institution.

Main text. The functioning of modern higher professional education is determined by the goals and objectives outlined in national and international regulations. The professional training of maritime specialists in particular is conducted in accordance with regulations of IMO (International Maritime Organization); changes in those regulations in turn cause improvement of modern training plans in maritime higher educational institutions. The result of training is a competent and competitive specialist of the maritime fleet, who is able to make the right decisions and perform actions (according to professional responsibilities) in different incidents on board: operation of technical equipment, cargo storage, proper management of his own activities and if necessary other participants of a working process, compliance with safety regulations on board the ship, rules and procedures in emergency situations and the implementation of all actions in case of danger, etc. Practical training of cadets of maritime educational institutions is a natural part of an educational process and an effective form of training specialists for employment. The purpose of the practical training is cadet's handling competence for professional activity, the capability to operate and perform the necessary repairs of equipment of modern diesel power plants. The main task of the practical training is the consolidation of theoretical knowledge gained by cadets while studying specialized subjects, formation of professional skills in accordance with the qualification profile and obtained professions, practical implementation of modern equipment and receiving of necessary professional experience in river and maritime fleet. In accordance with the curriculum, the practical training of cadets of the Maritime Applied College of the Kherson State Maritime Academy is carried out in 
three stages: 1. Practical training in the training workshop. 2. Practical training on training ships. 3 . Practical training on vessels of river and maritime fleet. All three stages of practice are interrelated: the practical skills acquired in the practical training the training workshop are used in the next two stages of practical training in the process of repair and maintenance work with ship machinery and equipment. And the knowledge and skills gained during practical training on vessels of river and maritime fleet are deepened and improved in educational swimming practice, in the following stages are deepened and improved (East European Scientific Journal, 2018:21-27).

Practical training on training ships is conducted on board of training ships. As an exception, this practice is allowed on transport vessels. In this case, the number of cadets sent depends on the availability of vacancies on the ship. If there are more cadets (8-10 people), it is recommended to send the head of the internship from the college to the transport vessels. Practical training on river and maritime fleet vessels is conducted on transport vessels equipped with modern automated power plants. The duration of the ship's flight on the line of transportation should be taken into account in order to exclude the possibility of cases of cadets being late from practical training. The important role in conducting all kinds of practical training (practical training in practical workshops and especially the one on training ships and on river and maritime fleet vessels) belongs to the application of English for the professional purposes not excluding its usage in everyday life. After all being on board of training ships as well as river and maritime fleet ships cadets consolidate and improve knowledge and skills of spoken English, the ability to talk about the vessel, its parameters, and features (cargo, design, etc.). During the practical training cadets acquire practical skills to perform daily work in the engine room, as well as on board the ship. They also improve the skills of indicating the ports of call, as well as describing the impression they've got from the practical training. In addition, cadets master the basic concepts and skills regarding the operation of the engine room machinery. Issues of life safety deserve special attention. Therefore, during the practical study of ship's devices and the power plant machinery in English the issues of safety on board the ship, rules and procedures in case of emergencies and the implementation of all actions in case of danger are carefully studied. In case of emergency standard English phrases are used in radio communication and messages from the Global Maritime Distress and Safety System (GMDSS). Hence, a thorough knowledge of English is necessary for the ship to function as a whole. So, in order to provide the efficient preparation of cadets for professional activity in foreign language environment (foreign language, multilingual crew) certain professional topics are trained in English in educational real-life situations.

At the stage of practical training on vessels of river and maritime fleet cadets consolidate and improve knowledge and skills in maintenance of systems and machinery of the ship's power plant; acquire practical skills in the management of main and auxiliary engines and assessment of their technical condition, as well as gain basic skills of shift maintenance of the power plant and electric drives of ship machinery. Moreover, cadets master basic concepts and skills on issues of preventive and planned repair works, shipyard overhaul.

In the practical study of ship devices and power plant machinery, special attention is paid to the automation of control processes, the principles of automation and the purpose of its installation. Along with the acquisition of professional skills and abilities, cadets consolidate and improve knowledge and skills in English on these issues. In addition, cadets master the basic concepts and skills of watchkeeping.

Scholars and practitioners emphasize the need for language proficiency (state and foreign) and therefore speech culture for maritime professionals. E. Kahvechi and H. Sampson note that the factors of successful work of multinational crews are to ensure that everyone has a basic knowledge of any common language before coming to serve on a ship; to promote the functioning of stable crews in which they could communicate in English hybrid language; to promote social events; to adopt and implement anti-racist policies and to draw attention to the ability of captains to treat people, whether they are newcomers or employees with longer service experience (Erol Kahveci et al, 2002). Each crew member's knowledge of English is very important for the implementation of joint work, both in the engine room and on the navigation bridge, and the clarity and relevance of this activity depends on its implementation. Based on research, surveys and forums, analyzing the feedback from ship owners, many maritime educational institutions have taken as a basis radical changes in the approach to teaching English, namely: consideration and discussion of real cases of emergencies in practical classes; use of English, both in and out of the class; creating mini-situations in which 
cadets can model their behavior and communication in multinational teams; use of Internet resources in order to improve computer and language literacy skills; development of speech skills in everyday situations, for example, talking in a mess room, during coffee breaks, etc. (Dyagyleva O.S., Yurzhenko A.Y., 2018: 92-98).

Classes of the course "English for professional communication" are conducted in order to complete the selected tasks cadets face during their practical training on board. Cadets are offered tasks aimed at the formation of professional competence, in particular, its component of speech culture (based on the English language).

In the conditions of distance learning, the task of forming professional competence in English has become somewhat more complicated. But thanks to the Moodle platform, which provides many opportunities for distance and blended learning, English language teachers of ship engineering department of MAC KSMA managed to maintain a high level of training of cadets for further practical training.

The English language teachers of ship engineering department of MAC KSMA use the following activities:

The Forum module allows participants to have asynchronous discussions, i.e. discussions that take place over a long period of time.

There are several types of forums to choose from, such as a standard forum, where anyone can start a new discussion at any time; a forum where each cadet can leave only one discussion; or a question-and-answer forum, where cadets must first send their first message before they can view other cadets' messages. A teacher can allow files to be attached to forum posts. Attached images are displayed directly in forum posts.

Participants can subscribe to a forum to receive notifications about new forum posts. A teacher can set the subscription mode as "optional", "forced" or "auto", or prohibit the subscription altogether. If necessary, cadets can be blocked from posting more than a specified number of messages in a given period of time; this measure will help to avoid getting cadets distracted from the dominant discussion.

Forums have multiple applications, namely

- Social space for cadets to get to know each other better;

- For long-term online discussion of controversial issues previously raised in face-to-face communication;

- As a help center where teachers and cadets can give advice;
- As a one-on-one support for the teacher's private communication with the cadet (using a forum with individual groups and with one cadet in a group);

- For advanced activities, such as "puzzles" for cadets to ponder and suggest solutions.

For example, a teacher can download a video and ask questions.

\section{Let's discuss}

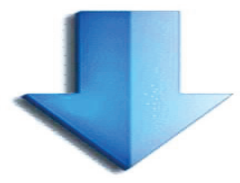

Role of English

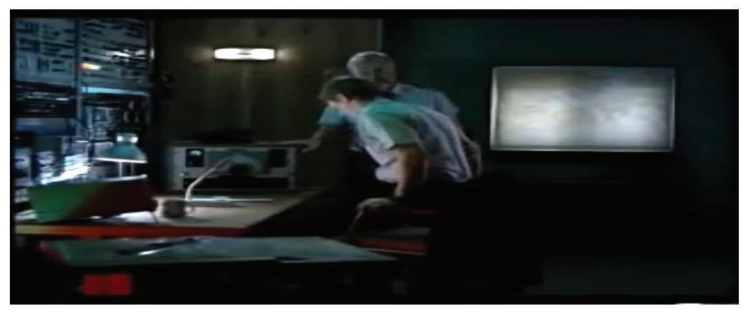

Picture 1. Example of Forum activity design

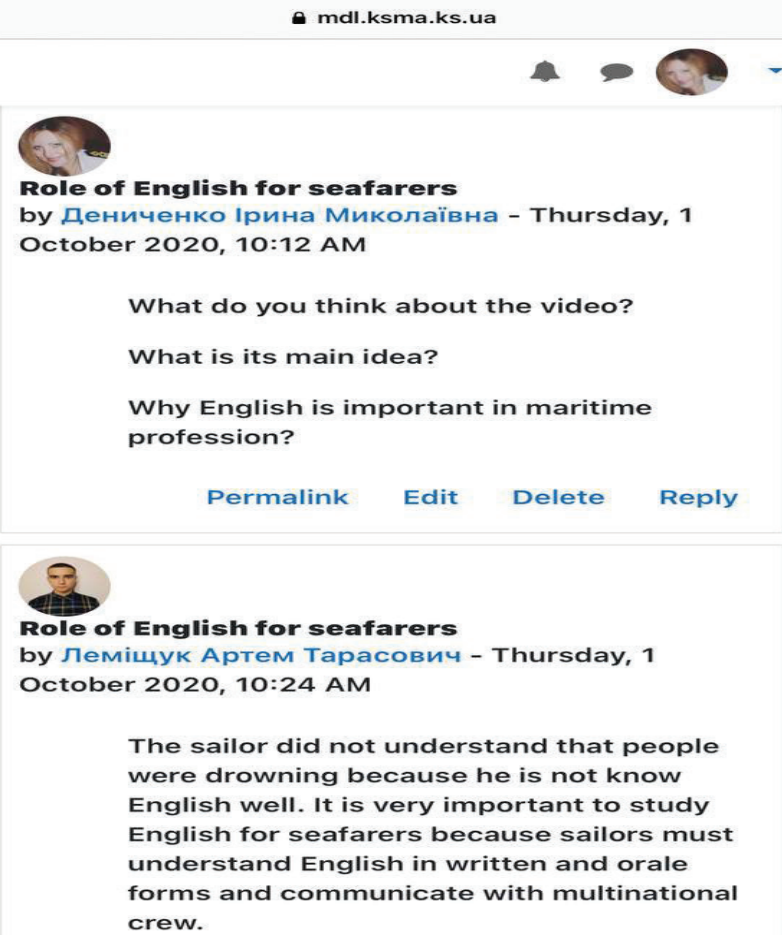

Picture 2. Example of cadets' answers at the Forum

Also, there's an opportunity to discuss any issue related to the professional sphere. 


\section{Discuss the questions}

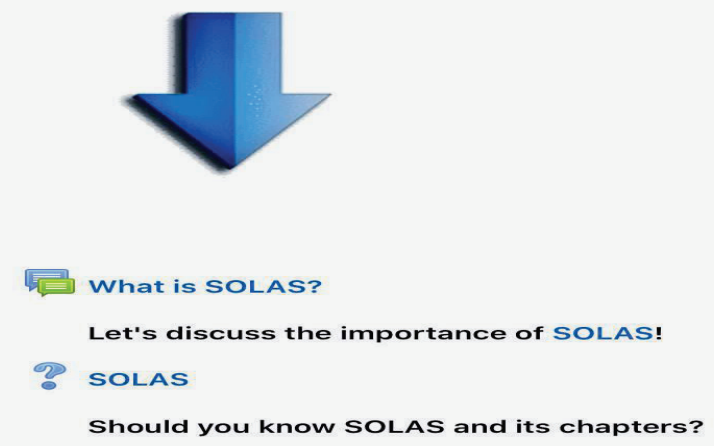

Picture 3. Example of professional sphere question design

- mol..ksma.ks.ua

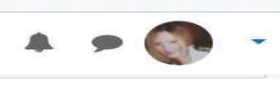

SOLAS

bу Сидякін Віктор Костянтинович - Tuesday, 6 October 2020, 10:42 AM

I think everyone should know all the chapters of solas. Because first of all it is your safety and your companions

$$
\text { Permalink Show parent Edit }
$$$$
\text { Split Delete Reply }
$$

Picture 4. Example of cadets' answers within professional topics

Cadets can even create their own discussions on a given topic and practice online conversation.

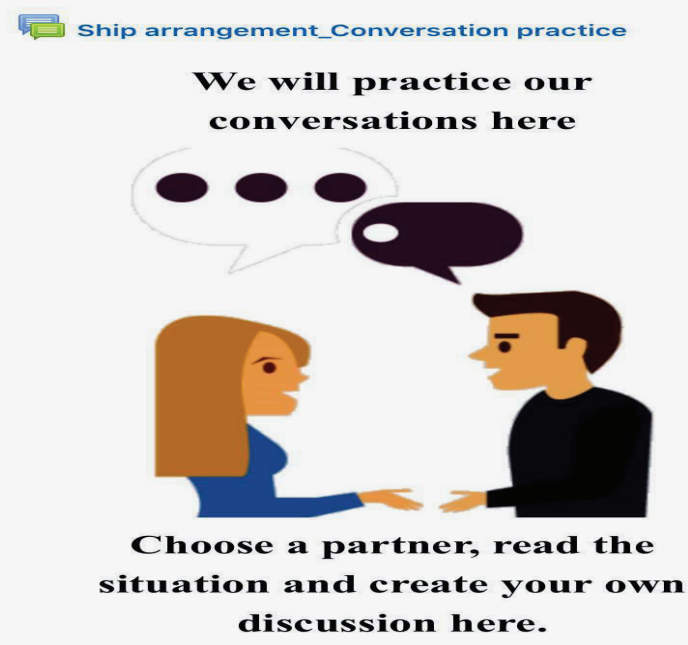

Picture 5. Example of cadet discussion design
In addition to the activities of the Forum, a lot of opportunities are provided by the activities of the Task.

Task activity module enables teachers to publish tasks, collect works, evaluate them and leave feedback on these works.

Cadets can send any digital content (files), such as text documents, spreadsheets, pictures, audio and video files. There is an option of allowing students to enter an answer directly in the editor on the site. The task can also serve as a reminder to students of what they need to do in the "real world", such as some creative work that cannot be digitized.

When considering a task, teachers can leave text reviews or files with a detailed explanation of the cadet's work.

A teacher can upload audio files with own questions, and a cadet can upload his own audio files in response. Thus, the understanding of language by ear is tested.

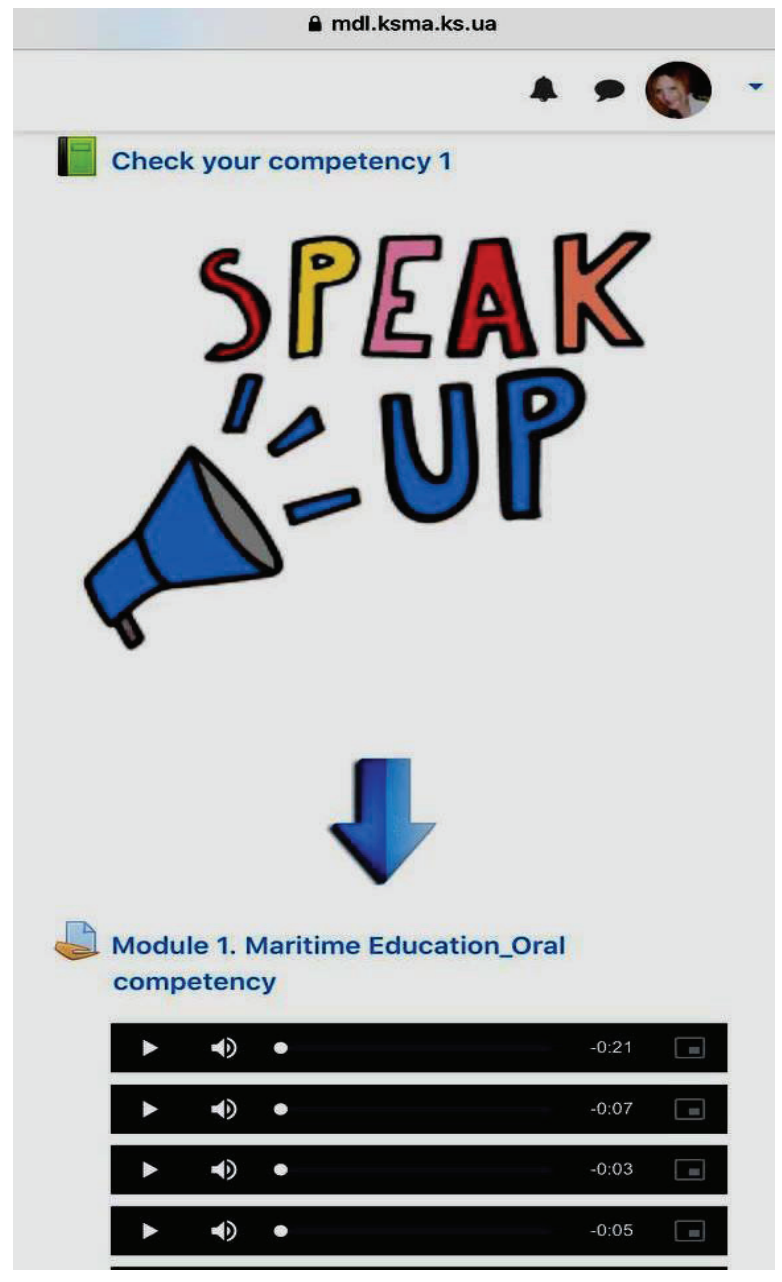

Picture 6. Example of design for the activity Task with audio files 
Module 1. Maritime Education_Oral competency

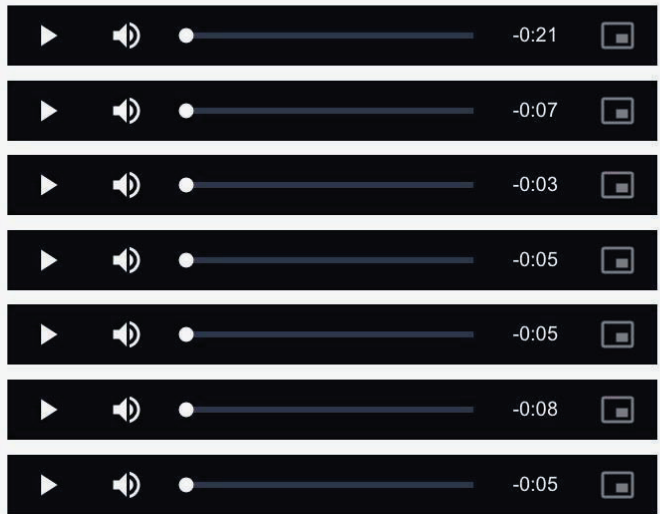

Picture 7. Example of audio files design

Picture 8. Example of cadets answers via audio files

A teacher can also give creative tasks, determine a plan and structure of work and collect them for testing through this activity.

Furthermore, teachers successfully use the Test activity to test the mastery of a material and to train certain skills, including the skill of passing professional tests before the practice of being qualified in maritime companies.

This module gives a teacher the opportunity to develop tests that may contain questions of different types, including multiple choice, matching, short answer and numerical.

A teacher can allow multiple test attempts; questions can be shuffled or randomly selected from the question bank. A time limit can also be set.

A teacher can choose whether to give students tips or show feedback and correct answers to questions.

\section{Project work}

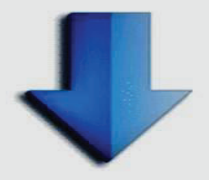

Module 2. Career awareness_project

Project work

Make a power point presentation on the Topic

"How to prepare for maritime career"

Follow the plan:

1. What does maritime career involve?

2. What are the benefits of maritime career?

3. What are the disadvantages of maritime career?

4. How to overcome the disadvantages of maritime career?

5. What document are required for the first sea practice?

6. What traits of character are important for the seafarer?

7. What makes you better than other cadets in your group?

8. What makes you ready for your future job?

Picture 9. Example of creative work design

Tests can be used:

- In course exams;

- As mini-tests in individual tasks or at the end of a topic;

- In exams that may use past exam questions;

- To receive feedback aimed to evaluate the efficiency of training;

- For self-control.

03.10.2020_Progress test 1_K-224

Restricted Not available unless:

- You belong to K-224

- You achieve a required score in Stop and check 1_k224

- You achieve a required score in

19.10.2020_Stop and Check 2_K224

- You achieve a required score in

02.11.2020_stop and check 3_k224

03.10.2020_Progress test 1_K-221

Restricted Not available unless:

- You belong to K-221

- You achieve a required score in stop and

check1_K221

- You achieve a required score in

19.10.2020_Stop and Check 2_K221

- You achieve a required score in

02.11.2020_Stop and check 3_K221

Picture 10. Example of Test activity design 
Conclusion. In our opinion, practical training on training vessels and on river and maritime fleet vessels (namely in the international crew) determines the success not only in the formation of professional competence, but also in the formation of speech culture of future maritime professionals, in particular: foreign language skills communication taking into account the specifics of the practical implementation of professional competence (performance of professional functions and responsibilities) in an international crew; stimulating the development of speech culture components of the future specialist of the maritime industry in the process of classroom training (study of professional subjects and foreign (English) language for the professional purpose).

\section{BIBLIOGRAPHY}

1. Kahveci E. et al. Transnational Seafarer Communities. Cardiff University 2002. URL: http://www.sirc.cf.ac.uk/6 Multinational_Crews.aspx (Last accessed: 25.08.2021).

2. STCW. International Convention on Standards of Training, Certification and Watchkeeping for Seafarers: approved by IMO in 1995 (amended in 2010). URL: http://www.seaobs.ru/sea programms/STCW95.pdf (Last accessed: 25.08.2021).

3. Дягилева О.С., Юрженко А.Ю. Запровадження моделі формування комунікативної англомовної компетентності у систему професійної підготовки майбутніх суднових механіків. Актуальні проблеми соиіології, психологіï, педагогіки. КНУ імені Тараса Шевченка, 2018. Том 3. № 38\39. С. 92-98.

4. Токарева О.В. Навчальна та виробнича практики на суднах як чинник формування мовленнєвої культури майбутніх фахівців морської галузі у процесі професійної підготовки. East European Scientific Journal. Bapшава. 2018. 2(30). C. 21-27.

5. Токарева О.В. Формування мовленнєвої культури майбутніх фахівців морської галузі: теоретичний аспект. Науковий журнал «Молодий вчений». Херсон. 2018. №3(55). С. 132-136.

6. Юрженко А.Ю., Волошинов С.А. Експериментальне дослідження сформованості англомовної комунікативної компетентності майбутніх суднових механіків. Наука України - погляд молодих вчених крізь призму сучасності: тези доповідей II Всеукраїнська науково-практичної конференції з міжнародною участю. Черкаси, 2019. С. 104-106.

\section{REFERENCES}

1. Kahveci E. et al. Transnational Seafarer Communities. Cardiff University 2002. URL: http://www.sirc.cf.ac.uk/6 Multinational_Crews.aspx (Last accessed: 25.08.2021).

2. STCW. International Convention on Standards of Training, Certification and Watchkeeping for Seafarers: approved by IMO in 1995 (amended in 2010). URL: http://www.seaobs.ru/sea_programms/STCW95.pdf (Last accessed: 25.08.2021).

3. Dyahyleva O.S., Yurzhenko A.Yu. Zaprovadzhennya modeli formuvannya komunikatyvnoyi anhlomovnoyi kompetentnosti u systemu profesiynoyi pidhotovky maybutnikh sudnovykh mekhanikiv [Introduction of the model of formation of communicative English competence in the system of professional training of future ship mechanics]. Aktual'ni problemy sotsiolohiyi, psykholohiyi, pedahohiky. KNU imeni Tarasa Shevchenka, 2018. Tom 3. № 38\39. S. 92-98. [in Ukrainian]

4. Tokareva O.V. Navchal'na ta vyrobnycha praktyky na sudnakh yak chynnyk formuvannya movlennyevoyi kul'tury maybutnikh fakhivtsiv mors'koyi haluzi u protsesi profesiynoyi pidhotovky [Training and production practice on ships as a factor in the formation of speech culture of future specialists in the maritime industry in the process of training]. East European Scientific Journal. Warsaw. 2018. 2(30). S. 21-27. [in Ukrainian]

5. Tokareva O.V. Formuvannya movlennyevoyi kul'tury maybutnikh fakhivtsiv mors'koyi haluzi: teoretychnyy aspect [Formation of speech culture of future specialists of the maritime industry: theoretical aspect]. Naukovyy zhurnal «Molodyy vchenyy». Kherson. 2018. №3(55). S. 132-136. [in Ukrainian]

6. Yurzhenko A.Yu., Voloshynov S.A. Eksperymental'ne doslidzhennya sformovanosti anhlomovnoyi komunikatyvnoyi kompetentnosti maybutnikh sudnovykh mekhanikiv [Experimental study of the formation of English-language communicative competence of future ship mechanics]. Nauka Ukrayiny - pohlyad molodykh vchenykh kriz' pryzmu suchasnosti: tezy dopovidey II Vseukrayins'ka naukovo-praktychnoyi konferentsiyi z mizhnarodnoyu uchastyu. Cherkasy, 2019. S. 104-106. [in Ukrainian] 